\title{
Greasing the wheels? The impact of regulations and corruption on firm entry
}

\author{
Axel Dreher • Martin Gassebner
}

Received: 9 February 2011 / Accepted: 5 August 2011 / Published online: 5 October 2011

(C) The Author(s) 2011. This article is published with open access at Springerlink.com

\begin{abstract}
This paper investigates the question of whether corruption might 'grease the wheels' of an economy. We investigate whether and to what extent the impact of regulations on entrepreneurship is dependent on corruption. We first test whether regulations robustly deter firm entry into markets. Our results show that the existence of a larger number of procedures required to start a business, as well as larger minimum capital requirements are detrimental to entrepreneurship. Second, we test whether corruption reduces the negative impact of regulations on entrepreneurship in highly regulated economies. Our empirical analysis, covering a maximum of 43 countries over the 2003-2005 period, shows that corruption facilitates firm entry in highly regulated economies. For example, the 'greasing' effect of corruption kicks in at around 50 days required to start a new business. Our results thus provide support for the 'grease the wheels' hypothesis.
\end{abstract}

Keywords Corruption · Start-ups · 'Grease the wheels' · Entrepreneurship · Regulation · Doing business

\footnotetext{
A. Dreher $(\bowtie)$

Alfred-Weber-Institute for Economics, Heidelberg University, Bergheimer Strasse 58, 69115 Heidelberg, Germany

e-mail: mail@axel-dreher.de
}

A. Dreher

University of Goettingen, Goettingen, Germany

A. Dreher

IZA, Bonn, Germany

A. Dreher - M. Gassebner

KOF Swiss Economic Institute, ETH Zurich, Weinbergstrasse 35, 8092 Zurich, Switzerland

M. Gassebner

e-mail: gassebner@kof.ethz.ch

A. Dreher - M. Gassebner

CESifo, Munich, Germany 
JEL Classification D73 $\cdot$ F59 $\cdot$ M13 $\cdot$ L26

\section{Introduction}

Recent work by Méon and Sekkat (2005) and Méon and Weill (2010) stresses the potential importance of corruption in 'greasing the wheels' of an economy. In this paper we follow their agenda and analyze whether and to what extent corruption-as one key feature of a country's institutional quality-affects the impact of regulations on entrepreneurship. The question of whether corruption might 'grease the wheels' of an economy has frequently been investigated in the context of economic growth. Routine corruption may well be efficiency enhancing. As Leff (1964: 11) states: "If the government has erred in its decision, the course made possible by corruption may well be the better one." Corruption may also 'grease the wheels' in rigid public administrations. As Huntington (1968: 386) notes: "In terms of economic growth, the only thing worse than a society with a rigid, over-centralized, dishonest bureaucracy is one with a rigid, over-centralized, honest bureaucracy." Corruption might be a means of achieving certain benefits that make work in the official economy easier, such as winning a contract from a public authority, getting a licence (e.g., for operating taxis or providing other services, or getting permission to convert land into "construction ready" land). However, the majority of the cross-country literature finds no evidence in favor of the greasing the wheels hypothesis, as Campos et al. (2010) show using meta-analysis. ${ }^{1}$

Arguably, while it might be difficult to find that corruption increases economic growth overall, focusing instead on market entry might change the verdict. This is because the effect is directly observable for a smaller unit of observation. In a recent paper, Vial and Hanoteau (2010) do indeed find empirical evidence supporting the greasing the wheels effect, using micro-level data on Indonesian firms which allows for the measurement of corruption and growth at the plant level.

In this paper we take an intermediate approach between the macroeconomic corruption and growth studies and the microeconomic single country studies. We analyze empirically whether corruption affects the impact of strict regulations on entrepreneurial activity at the international level. This means we will be taking a macro-perspective but stop short of testing an economy-wide growth effect. As our measures of corruption we employ two datasets provided by Transparency International and the World Bank, respectively. Data on regulation are taken from the World Bank's Doing Business Database and the Economic Freedom Index developed by the Fraser Institute.

While the impact of strict regulations on entrepreneurial activity has been the subject of previous research, the hypotheses have mostly been tested in an ad hoc manner-using models which lack potentially relevant control variables, most likely implying biased results. In depth tests for robustness are also lacking. With this in mind, prior to analyzing our main question, we develop a robust empirical model for the determinants of entrepreneurial activity. Specifically, we employ extreme bounds analysis (EBA) as proposed by Leamer (1983), Levine and Renelt (1992) and Sala-i-Martin (1997) for a panel of 43 countries over the 2003-2005 period to identify the variables which are robust. Being instrumental to the main question, the analysis fills a gap in the literature in its own right.

\footnotetext{
${ }^{1}$ Mauro (1998), for example, investigates the impact of corruption on economic growth for separate samples of high and low red tape countries. His results show no evidence in favor of a beneficial effect of corruption. Méon and Sekkat (2005) find some evidence that corruption even sands the wheels of the system (instead of greasing them). Specifically, Méon and Sekkat show that the negative impact of corruption on economic growth becomes worse when indicators of the quality of governance deteriorate.
} 
To foreshadow the results of our analysis, we find that, on average, more procedures required to start a business and larger minimum capital requirements robustly reduce the number of entrepreneurs entering the market. However, corruption seems to reduce the negative impact of regulations on firm entry. This means that we find evidence in favor of the 'grease the wheels' hypothesis.

We proceed as follows. The next section develops our main hypothesis on the interaction between regulations and corruption, while our data are described in Sect. 3. In Sect. 4, we test whether regulations robustly affect firm entry; Sect. 5 tests our main hypothesis. The final section concludes the paper.

\section{The hypothesis}

According to public choice theory, special interest groups benefit from particular government actions, albeit at the cost of overall efficiency and well-being (Stigler 1971). As the individual benefits for each member of a small special interest lobbying group are substantial, whereas the costs to the average member of society are rather small, governments become larger and larger as politicians maximize their re-election possibilities by catering to powerful special interests. According to classical economic theory, on the contrary, the state remedies market failures by producing important public goods (Musgrave 1959), levying Pigouvian taxes (Pigou 1928) and providing institutional frameworks, without which the markets would not work efficiently or even function at all (Blankart 2003). According to the public choice view, regulation is acquired by industries and designed for their benefit, while the public interest perspective implies that regulation is required to reduce inefficiencies and achieve socially optimal outcomes.

Arguably, depending on one's view of the purposes and effects of regulatory intervention, it can either be beneficial or harmful and, consequently, ways to overcome these regulations may or may not be welcome. Clearly, one way to circumvent regulation is by bribing officials. In corrupt countries, officials can easily be bribed to issue permits, potentially facilitating entrepreneurial activity and, in particular, firm entry into the official market. Corruption might be seen as increasing the 'speed of money', which considerably reduces slow-moving queues in public offices, for example.

The 'grease the wheels' hypothesis features prominently in the early literature on the effects of corruption (e.g., Leff 1964; Leys 1965; Huntington 1968). Beck and Mahler (1986) and Lien (1986) also proposed that corruption increases efficiency. Nye (1967) argues that corruption might be a way to overcome discrimination against members of a minority group, which could actually prevent entrepreneurs from accessing markets. This is because inefficient regulations constitute an impediment to investment that can be overcome by bribing bureaucrats.

Méon and Sekkat (2005) summarize the arguments brought forward in favor of the 'grease the wheels' hypothesis. First, corruption can increase the speed with which bureaucrats issue permits. Bribes therefore serve the function of giving incentives to bureaucrats by speeding up this process (Leys 1965; Lui 1985). Méon and Sekkat cite Huntington (1968), arguing that corruption speeds up railroad, utility, and industrial corporation construction, resulting in higher growth.

Second, corruption might improve the quality of the civil service (Leys 1965; Bailey 1966). This is because inefficiently low wages are supplemented by graft, increasing the attractiveness of jobs in the administration, in turn increasing the quality of civil servants.

Third, licenses might be allocated more efficiently when the most efficient firm can pay the highest bribe (Leff 1964; Beck and Mahler 1986; Lien 1986). 
In summary, graft may be a hedge against bad public policy, in particular when institutions are biased against entrepreneurship (Méon and Sekkat 2005).

The empirical literature on corruption has clearly established that it has a negative impact on economic growth (e.g., Méon and Sekkat 2005). This seems to be inconsistent with the 'grease the wheels' hypothesis. However, as Méon and Sekkat (2005) point out, the negative impact of corruption on growth, per se, is not inconsistent with the hypothesis. According to the 'grease the wheels' hypothesis, corruption is not beneficial on average, but only when regulation is excessive. Moreover, corruption might affect growth via various channels. For example, corrupt officials might create distortions in the system in order to protect their illegal income (Kurer 1993). ${ }^{2}$ Firms may be able to pay the highest bribe, and thus gain a particular contract, just by compromising on the quality of the product (Rose-Ackerman 1997). Corruption might increase uncertainty, thereby increasing risks (Campos et al. 1999). Economic growth would consequently deteriorate. Even if the negative effect of corruption prevails overall, the true test is whether corruption helps in circumventing strict regulations. Despite the overall impact of corruption on growth being negative, it may still promote entrepreneurial activity which has been suppressed by rigid regulations.

Empirical evidence in support of the 'grease the wheels' hypothesis does already exist. Evidence from Indonesia has already been alluded to in the introduction, for example (Vial and Hanoteau 2010). According to Méon and Weill (2010), corruption reduces aggregate efficiency in countries where institutions are effective, yet increases efficiency where institutions are ineffective. ${ }^{3}$ They distinguish between a weak and strong form of the hypothesis. The weak form states that corruption is less damaging in countries with weak institutions, while the strong form states that corruption is actually beneficial in a defective institutional environment. Moreover, a cross-industry analysis by Klapper et al. (2006) provides preliminary evidence that although regulatory barriers to firm entry do not adversely affect market entry in corrupt countries, they do in less corrupt ones. This is exactly in line with the 'grease the wheels' hypothesis: Less rigidity implies less "need" for corruption.

We therefore hypothesize:

Corruption increases firm entry rates in the presence of administrative barriers to entry.

\section{Data}

Our definition of entrepreneurship follows Wennekers and Thurik (1999: 46-47), defining entrepreneurship as "the manifest ability and willingness of individuals" to perceive new economic opportunities and seize them in the face of uncertainty in the market. We use data provided by the Global Entrepreneurship Monitor (GEM). The GEM dataset contains survey-based annual data on early stage entrepreneurial activity for 43 countries since $2001 .{ }^{4}$ The surveys in the different countries generally are conducted by local universities. Representative samples of at least 2,000 individuals are drawn annually for each country. The

\footnotetext{
${ }^{2}$ This is in line with the evidence in Anderson and Tverdova (2003), showing that people perceive more corrupt political systems to be less efficient, on average.

${ }^{3}$ The efficiency-enhancing view of corruption has also been criticized however (see, e.g., Tanzi 1998; RoseAckerman 1999; Kaufmann and Wei 2000). Kaufman and Wei (2000) report that multinational firms paying more bribes also spend more time negotiating with foreign officials, working against the 'grease the wheels' hypothesis.

${ }^{4}$ The EIM Public Knowledge Web on SMEs (Small and Medium-Sized Enterprises) and Entrepreneurship provides the dataset at http://data.ondernemerschap.nl/webintegraal/userif.aspx.
} 
detailed list of partner institutions and the number of people interviewed, as well as more information about these interviews are available in Minniti et al. (2005: 4-8, 57). We focus on the percentage of the adult population who are 'nascent' entrepreneurs, defined as "those individuals, between the ages of 18 and 64 years, who have taken some action toward creating a new business in the past year. ${ }^{5}$ To qualify for this category, individuals must also expect to own a share of the business they are starting and the business must not have paid any wages or salaries for more than three months" (Minniti et al. 2005: 16). The measure is not ideal given that the stock of nascent entrepreneurs may be larger in countries where stricter regulations lead to a longer procedure for starting a business. However, we control for regulations in our analysis below. Also note that we replicate the analysis focusing on firms that have existed for longer than three months but less than 42 months. Our results do not depend on this choice.

In our subsequent empirical analysis, one central set of variables refers to regulation. As we maintain a particular focus on regulations that apply to starting a business, we incorporate the following four variables into our empirical model (taken from the Doing Business Dataset provided by the World Bank) ${ }^{6}$ : The number of procedures required to start a new business, the number of days required to start a new business, the costs of starting a new business, and the minimum capital required to start a new business. The data are available for 175 countries from 2003 onwards. The data focus on start-ups of limited liability companies which are owned by five local nationals and operate in the respective country's largest city. Procedures are defined as any interaction between the founders and external parties necessary to complete the start-up process legally. The number of required procedures in our sample ranges between 2 and 19. The days required to start a business captures the median duration that business incorporation lawyers deem to be necessary to complete the founding process. This measure ranges from 2 to 168. The start-up costs for a new business are measured as a percentage of the respective country's income per capita. Only official costs are recorded, which guarantees that there is no direct relation to our corruption measures. The data range for this variable is 0 to 147 . The minimum capital required to start a business is the amount that the entrepreneur needs to deposit in a bank before registering the company. It is also measured as a percentage of the country's income per capita, ranging between $0-947.7$

In addition to these four indices, we employ the sub-index on regulations from the Economic Freedom Index developed by Gwartney and Lawson (2006). The index ranges from $0-10$, with 10 indicating the highest value of economic freedom on the original scale. We reverse the index in order to ensure that our regulation measures all flow in the same direction, i.e., higher numbers will now indicate stricter regulations. The index covers credit market regulations, labor market regulations, and business regulations, employing a wide range of variables (including some of the measures of regulations we use here).

To measure corruption, we employ two well-known and widely used indices. The first indicator is provided by Transparency International (TI), ranging from 0 to 10 . The second index is from the World Bank's 'governance matters' database (Kaufmann et al. 2006) with

\footnotetext{
${ }^{5}$ The exact question the respondent has to answer is: "Over the past twelve months have you done anything to help start this new business, such as looking for equipment or a location, organizing a start-up team, working on a business plan, beginning to save money, or any other activity that would help launch a business?" (http://www.gemconsortium.org/download.asp?fid=410, accessed January 11, 2008).

${ }^{6}$ The data are available at http://www.doingbusiness.org/.

${ }^{7}$ Note that all regulation proxies are obtained by interviewing knowledgeable lawyers in each country. As we are interested in the legal regulatory benchmark, this does not constitute a problem for our analysis.
} 
values between -2.51 and 1.71 . We have rescaled the two indices, so that higher values represent more corruption.

Our selection of control variables follows the previous literature. Among the economic variables included in the vast majority of previous empirical specifications, GDP per capita features most prominently. However, whether per capita GDP actually affects entrepreneurship is still debatable. According to Ovaska and Sobel (2005), there is no significant impact on the number of new enterprises per 1000 inhabitants. On the contrary, Parker and Robson (2004) show that per capita GDP increases entrepreneurship. Others report that GDP per capita reduces entrepreneurial activity (van Stel et al. 2003; Nooederhaven et al. 2004; Bjørnskov and Foss 2008; Wennekers et al. 2007). Van Stel et al. (2003), however, find nascent entrepreneurship to be more prevalent as the square of per capita GDP rises, suggesting a u-shaped relationship. The u-shaped impact of per capita GDP on entrepreneurship is confirmed in Verheul et al. (2006), with an implied turning point of around USD 26,000. A potential explanation for this is that development might be accompanied by raising real wages, in turn raising the opportunity costs of self-employment. Starting from a certain level of development the service sector gains in importance, favoring entrepreneurship.

Another recurring theme in the literature is the hypothesis that post-Communist countries exhibit significantly lower levels of entrepreneurship while-at the same timeexperiencing faster growth rates, as private economic involvement has been suppressed under communism. Empirical results on the impact of entrepreneurship are, however, not entirely conclusive. Van Stel et al. (2003), Verheul et al. (2006), and Freytag and Thurik (2007) report entrepreneurship to be less prevalent in former communist countries, while Bjørnskov and Foss (2008) do not find a significant impact of (former) communism on total entrepreneurial activity.

A glance at Appendix B shows that a wide array of other variables has been proposed but there is by no means a consensus on the determinants of start-up activity. All variables, with their sources, are presented in Appendix B, while Appendix C lists the countries included in our sample. Note that not all variables used in the prior literature could be incorporated into our panel set-up due to missing observations.

\section{Do regulations prevent entry?}

Desai et al. (2003) draw on regulatory data at the country level provided by the World Bank. The World Bank measures several factors, including the number of procedures required to start a company and those required to enforce a contract. According to the results in the overall sample of Desai et al. entry barriers do not robustly affect nascent entrepreneurshipa result also reported in van Stel et al. (2003). This is in contrast to Klapper et al. (2006), also drawing from the World Bank database, who show that the costs of entry (measured in terms of money outlays) reduce the fraction of new firms significantly. While these studies employ different dependent variables - so their results cannot be compared directly - the difference in regression outcomes might be due to the methodological refinement in Klapper et al. (2006), taking the fraction of new firms entering the US market as proxy for 'natural entry barriers' into account. Similarly, Ciccone and Papaioannou (2007) show that government entry restrictions reduce entry in industries experiencing expansionary global demand and technology shifts.

In their firm-level analysis for nine countries, Scarpetta et al. (2002) confirm the importance of regulations for entrepreneurial outcomes. They show that entry rates are significantly lower with stricter administrative regulations and stricter sector specific product 
market regulations. Ovaska and Sobel (2005) and Bjørnskov and Foss (2008) investigate the impact of economic freedom on entrepreneurial activity which we argue is an alternative measure for the role of regulations. Neither study finds strong evidence for the role of regulation. Employing the same data as Bjørnskov and Foss, Freytag and Thurik (2007) show that the degree of regulation significantly diminishes entrepreneurial activity.

Turning to our institutional variable of primary interest — corruption-Desai et al. (2003) show that firm entry rates are not significantly affected by corruption in both their overall sample and the Eurozone, while corruption significantly reduces entry in Central and Eastern European countries. Ovaska and Sobel (2005) find corruption to significantly reduce the number of new enterprises (per 1000 capita).

Before we turn to testing whether corruption affects the impact of regulations on firm entry, we analyze whether regulations robustly affect firm entry in the first place, using extreme bounds analysis (EBA). The EBA has been proposed by Leamer (1983) and Levine and Renelt (1992); it enables us to identify the explanatory variables that are related robustly to our entrepreneurial measure. EBA has been widely used in the existing literature on economic growth. The main difficulty in this area of research-which also applies to the research topic of this paper-is that the use of several different models may seem reasonable given the data, yet yield different conclusions regarding the parameters of interest. The EBA can be exemplified as follows. Equations of the following general form are estimated:

$$
Y=\beta_{M} M+\beta_{F} F+\beta_{Z} Z+v
$$

where $Y$ is the dependent variable, $M$ is a vector of commonly accepted explanatory variables and $F$ is a vector containing the variables of interest. The vector $Z$ contains up to three possible additional explanatory variables (as in Levine and Renelt 1992) which, according to the previous literature, are related to the dependent variable. The error term is $v$. The EBA test for a variable in $F$ states that if the lower extreme bound for $\beta_{F}$-i.e., the smallest value for $\beta_{F}$ minus two standard deviations - is negative, while the upper extreme bound for $\beta_{F}$-i.e., the largest value for $\beta_{F}$ plus two standard deviations-is positive, the variable $F$ is not robustly related to $Y$.

As argued by Temple (2000), it is rare in empirical research that we can say with certainty that one model dominates all other possibilities in every dimension. In these circumstances, it makes sense to provide information about how sensitive the findings are to alternative modelling choices. The EBA provides a relatively simple means of doing exactly that. Nevertheless, the EBA has been criticized in the literature. Sala-i-Martin (1997) argues that the test applied in the extreme bounds analysis poses too rigid a threshold in most cases. If the distribution of $\beta$ has both positive and negative support, then we are bound to find at least one regression in which the estimated coefficient changes sign if enough regressions are run. We will therefore not only report the extreme bounds, but also the percentage of the regressions in which the coefficient of the variable $F$ is significantly different from zero at the $5 \%$ level. Moreover, instead of analyzing just the extreme bounds of the estimates of the coefficient for a particular variable, we follow Sala-i-Martin's (1997) suggestion to analyze the entire distribution. We report not only the unweighted parameter estimate of $\beta$ and its standard deviation, but also the unweighted cumulative distribution function (CDF), i.e., the fraction of the cumulative distribution function lying on one side of zero. ${ }^{8}$ We base our

\footnotetext{
${ }^{8}$ In contrast to Sala-i-Martin, who suggests weighting results according to the goodness-of-fit of each regression, we use the unweighted mean parameter estimate of $\beta_{F}$, mean standard error, and CDF. This is because missing data pose a problem. The number of observations changes depending on which variables are included
} 
conclusions on the Sala-i-Martin variant of the EBA. In line with Sala-i-Martin, a variable is considered to be robustly related to nascent entrepreneurship if the CDF value is greater than or equal to $0.9 .{ }^{9}$

Another potential objection to the EBA is that the initial partitions of variables in the $M$ and $Z$ vectors are likely to be arbitrary. However, as pointed out by Temple (2000), there is no reason why standard model selection procedures cannot be used in advance to identify variables that are especially relevant.

Arguably, some variables included in the vast majority of previous empirical studies are now commonly used. The variables most often used are per capita GDP and its square, and a dummy for post-Communist countries.

In addition to these three variables, our EBA introduces the regulation measures above one at a time; i.e., we run one EBA for each of our five measures of regulation. The remaining variables, as described in Appendix B, are introduced in combinations of up to three variables. We estimate the regressions using OLS with standard errors corrected for panellevel heteroscedasticity (panel-corrected standard errors; see Beck and Katz 1996). We also correct for first-order autocorrelation $\mathrm{AR}(1)$ of the error term within panels, restricting the coefficients of the AR(1) process to be equal in all panels, as suggested by Beck and Katz (1995). Moreover, we use the Prais-Winsten transformation, as this enables us to preserve the first observation for each panel. As Beck and Katz (1995) argue, OLS with corrected standard errors (as described above) is generally preferable to Feasible Generalized Least Squares. ${ }^{10}$

The results of our final models reported below include 93 observations from 43 countries. Among the sample, 14 countries enter with one observation, eight with two and 21 with three. Most variables included in the regressions vary over time. Consequently, we prefer panel models to approach the data. However, our results do not depend on this choice. When we replicate the analysis using averages of all variables over the sample period and run a pure cross-section analysis, our results remain qualitatively unchanged. They are available on request.

Table 1 shows the results of the EBA. The first three rows report the results for the base variables included in the $M$-vector of the EBA together with the number of procedures in the $F$-vector, based on 4,691 regressions. As can be seen, GDP per capita and its square easily pass Sala-i-Martin's robustness criterion. The implied turning point of the u-shaped relationship between income and entrepreneurial activity is approximately USD 27,000 per capita. This finding is in line with Verheul et al. (2006), reporting the turning point to be around USD 26,000.

Our results also confirm the relevance of communist heritage. Countries with a communist background have robustly lower levels of entrepreneurship (on average $5.5 \%$ over all

in each regression. Thus, the dataset essentially changes. In this context, Sturm and de Haan (2002) show that the goodness-of-fit measure may not be a good indicator of the probability that a model is the true model, and that the weights constructed in this way are not invariant to linear transformations of the dependent variable.

${ }^{9}$ An obvious alternative to the EBA is Bayesian Averaging of Classical Estimates (BACE) developed by Sala-i-Martin et al. (2004). While this procedure has the advantage that no assumption has to be made about the baseline model or the number of variables in the final model, it can be employed only for either a crosssection or balanced panel setting. As our panel is unbalanced, we did a BACE analysis for the cross sections of individual years among our sample. The results show similar patterns as the EBA but are less reliable due to the small number of observations. The results are available on request.

${ }^{10}$ We have also estimated a generalized linear model using a generalized estimating equation (GEE) with an $\mathrm{AR}(1)$ correlation structure. The results remain unchanged and are available on request. 
Table 1 Extreme bounds analysis results-dependent variable: nascent entrepreneurship

\begin{tabular}{lllll}
\hline Variable & Avg. beta & Avg. S.E. & \%Sig & CDF \\
\hline Lagged GDP per capita & -0.0007 & 0.0003 & 72.32 & 0.93 \\
Lagged GDP per capita squared & $1.37 \mathrm{E}-08$ & $5.83 \mathrm{E}-09$ & 73.23 & 0.94 \\
Dummy for communist history & -5.45 & 2.06 & 71.68 & 0.97 \\
Procedures required to start a business & -0.35 & 0.17 & 65.19 & 0.90 \\
Minimum capital required to start a business & -0.03 & 0.01 & 87.56 & 0.97 \\
Days required to start a business & -0.01 & 0.02 & 42.64 & 0.77 \\
Costs of starting a business & -0.08 & 0.07 & 60.08 & 0.68 \\
Economic Freedom regulation sub-index & -0.81 & 0.46 & 55.90 & 0.87 \\
\hline
\end{tabular}

Notes: The results are based on 4,691 regressions. 'Avg. beta' reports the average coefficient while 'Avg S.E.' indicates the average standard error of all regressions. ' $\%$ Sig' shows the percentage of regressions in which the coefficient is statistically different from zero at the $5 \%$ level at least. ' $C D F$ ' shows the (unweighted) mass of the larger part of the distribution of the estimated coefficients (i.e., the value is always greater or equal to 0.5 ). The criterion for a variable to be considered as robust is a value of 0.9 or above. The estimation technique applied is OLS with heteroscedastic panel-corrected standard errors and an AR(1) error term that is common across panels

regressions run). With respect to the variables previously proposed in the literature, the result of the EBA confirms the findings of earlier studies. As can be seen in Appendix B, only three variables pass the CDF criterion of 0.9 or above: The average income tax, secondary school enrolment, and the share of tax revenue in GDP. All other variables fail to meet the robustness criterion.

Turning to our variables of primary interest, the results show that some regulations seem to be robust determinants of entrepreneurship. ${ }^{11}$ Specifically, the number of procedures required to start a new business reduces entrepreneurial activity and thus constitutes a barrier to entry. The minimum capital required to start a business also reduces the level of entrepreneurship. The number of days and the out-of-pocket costs required to start a business do not pass the critical threshold, however, and thus cannot be considered to be robust determinants of entrepreneurial activity. The same is true for the Economic Freedom sub-index focusing on regulations.

As we pointed out earlier, however, the level of regulation is only part of the story. Even if regulations do not prevent firm entry on average, this might be due to people offering bribes to circumvent the regulations. In the absence of corruption, regulations might still be harmful, even if on average they are not. We turn to this issue in the next section.

\section{Does corruption 'grease the wheels' of entrepreneurship?}

Table 2 presents evidence supporting the 'grease the wheels' hypothesis. Due to the high correlation between the various measures of regulation, we include them in the base regression introduced above one at a time. ${ }^{12}$ The Transparency International index of corruption

\footnotetext{
${ }^{11}$ The EBA includes our measures of regulation one at the time to avoid multicollinearity.

${ }^{12}$ In Tables 2 and 3 we exclude the three additional variables that passed the EBA criterion as they decrease the number of observations by approximately $1 / 3$. To check for the robustness of our results, we replicated all our regressions including the three variables. Our findings remain mostly unchanged.
} 
Table 2 Nascent entrepreneurship and corruption (Transparency International), 2003-2005

\begin{tabular}{|c|c|c|c|c|c|}
\hline & (1) & (2) & (3) & (4) & (5) \\
\hline Lagged GDP per capita & $\begin{array}{l}-0.0007 \\
(3.20)^{* * *}\end{array}$ & $\begin{array}{l}-0.0008 \\
(3.18)^{* * *}\end{array}$ & $\begin{array}{l}-0.0007 \\
(3.71)^{* * *}\end{array}$ & $\begin{array}{l}-0.0007 \\
(3.46)^{* * *}\end{array}$ & $\begin{array}{l}-0.0007 \\
(3.62)^{* * *}\end{array}$ \\
\hline $\begin{array}{l}\text { Lagged GDP per capita } \\
\text { squared }\end{array}$ & $\begin{array}{l}1.28 \mathrm{E}-08 \\
(2.99)^{* * *}\end{array}$ & $\begin{array}{l}1.63 \mathrm{E}-08 \\
(3.29)^{* * *}\end{array}$ & $\begin{array}{l}1.21 \mathrm{E}-08 \\
(3.32)^{* * *}\end{array}$ & $\begin{array}{l}1.42 \mathrm{E}-08 \\
(3.28)^{* * *}\end{array}$ & $\begin{array}{l}1.20 \mathrm{E}-08 \\
(3.08)^{* * *}\end{array}$ \\
\hline $\begin{array}{l}\text { Dummy for communist } \\
\text { history }\end{array}$ & $\begin{array}{l}-5.6715 \\
(3.50)^{* * *}\end{array}$ & $\begin{array}{l}-5.5242 \\
(3.82)^{* * *}\end{array}$ & $\begin{array}{l}-5.3483 \\
(4.27)^{* * *}\end{array}$ & $\begin{array}{l}-6.3076 \\
(3.45)^{* * *}\end{array}$ & $\begin{array}{l}-6.2299 \\
(4.18)^{* * *}\end{array}$ \\
\hline $\begin{array}{l}\text { Transparency } \\
\text { International corruption }\end{array}$ & $\begin{array}{l}-0.3095 \\
(0.91)\end{array}$ & $\begin{array}{c}-0.1119 \\
(0.32)\end{array}$ & $\begin{array}{l}-0.7443 \\
(2.19)^{* *}\end{array}$ & $\begin{array}{l}-0.7679 \\
(1.41)\end{array}$ & $\begin{array}{c}-1.1236 \\
(1.69)^{*}\end{array}$ \\
\hline $\begin{array}{l}\text { Costs of starting a } \\
\text { business }\end{array}$ & $\begin{array}{l}-0.1804 \\
(2.99)^{* * *}\end{array}$ & & & & \\
\hline Corruption $*$ costs & $\begin{array}{c}0.0345 \\
(2.80)^{* * *}\end{array}$ & & & & \\
\hline $\begin{array}{l}\text { Minimum capital required } \\
\text { to start a business }\end{array}$ & & $\begin{array}{l}-0.0753 \\
(4.39)^{* * *}\end{array}$ & & & \\
\hline $\begin{array}{l}\text { Corruption } * \text { capital } \\
\text { required }\end{array}$ & & $\begin{array}{c}0.0106 \\
(4.20)^{* * *}\end{array}$ & & & \\
\hline $\begin{array}{l}\text { Days required to start a } \\
\text { business }\end{array}$ & & & $\begin{array}{l}-0.1149 \\
(4.91)^{* * *}\end{array}$ & & \\
\hline Corruption $*$ days & & & $\begin{array}{c}0.0246 \\
(4.56)^{* * *}\end{array}$ & & \\
\hline $\begin{array}{l}\text { Procedures required to } \\
\text { start a business }\end{array}$ & & & & $\begin{array}{l}-0.8919 \\
(4.98)^{* * *}\end{array}$ & \\
\hline Corruption $*$ procedures & & & & $\begin{array}{c}0.1441 \\
(2.99)^{* * *}\end{array}$ & \\
\hline $\begin{array}{l}\text { Economic Freedom } \\
\text { regulation sub-index }\end{array}$ & & & & & $\begin{array}{l}-1.5721 \\
(2.80)^{* * *}\end{array}$ \\
\hline Corruption $*$ regulation & & & & & $\begin{array}{c}0.2773 \\
(1.65)^{*}\end{array}$ \\
\hline Constant & $\begin{array}{l}13.6393 \\
(4.55)^{* * *}\end{array}$ & $\begin{array}{l}14.4107 \\
(4.09)^{* * *}\end{array}$ & $\begin{array}{l}14.8595 \\
(5.90)^{* * *}\end{array}$ & $\begin{array}{l}17.7612 \\
(6.86)^{* * *}\end{array}$ & $\begin{array}{l}18.7425 \\
(6.89)^{* * *}\end{array}$ \\
\hline $\begin{array}{l}\text { M.E. of corruption cond. } \\
\text { on regulation ( } \mathrm{min})\end{array}$ & -0.31 & -0.11 & $-0.70^{* *}$ & -0.48 & $-0.71^{*}$ \\
\hline $\begin{array}{l}\text { M.E. of corruption cond. } \\
\text { on regulation }(\max )\end{array}$ & $4.22^{* * *}$ & $9.94^{* * *}$ & $3.00^{* * *}$ & $1.68^{* * *}$ & 0.46 \\
\hline Observations & 93 & 91 & 93 & 93 & 122 \\
\hline Countries & 43 & 42 & 43 & 43 & 42 \\
\hline $\begin{array}{l}\text { Joint significance } \\
\text { (p-value) }\end{array}$ & 0.025 & 0.000 & 0.000 & 0.000 & 0.011 \\
\hline R-squared & 0.55 & 0.52 & 0.58 & 0.56 & 0.50 \\
\hline
\end{tabular}

Notes: Corruption is measured on a scale between 0 and 10, with larger values indicating more corruption. Higher values of all regulation variables indicate stricter regulation. Estimation is with heteroscedastic panelcorrected standard errors OLS and common AR(1) error term across panels. Joint significance refers to the p-value of a Wald test on corruption, the respective measure of regulation, and their interaction. Absolute Z-statistics are given in parentheses. M.E. of corruption cond. on regulation represents the marginal effect of corruption conditional on the minimum ( $\min )$ and maximum $(\max )$ of the regulation measure in the estimation sample

* Significant at $10 \% ;{ }^{* *}$ significant at $5 \% ;{ }^{* * *}$ significant at $1 \%$ 
enters the baseline regression separately and as an interaction with the respective measure of regulation. Note that this setup does not imply that corruption and regulation cannot be determined by the same set of variables in the long run. As one example, consider bureaucrats introducing restrictions that enable them to extract bribes (e.g., Dreher and Siemers 2009). However, what we ask here is a different question; namely, whether at a certain point in time for any given level of regulations, the impact of these regulations is affected by the existing level of corruption at the same point in time.

In all five regressions reported in Table 2, entrepreneurial activity decreases with (lagged) GDP per capita and increases with its square, at the $1 \%$ level of significance. ${ }^{13}$ Also at the $1 \%$ level, less entrepreneurial activity is predicted in countries with communist histories. The non-linear relationship between per capita GDP and nascent entrepreneurship implies that an increase in per capita GDP by USD 1,000 reduces the number of new entrepreneurs (relative to the adult population) by about $0.8 \%$ at the minimum (USD 261). At the mean of USD 18,000 , there is a $0.3 \%$ reduction, while at the maximum value of USD 39,000, start up activity is increased by $0.3 \%$. Post-Communist countries have between $5.3 \%$ and $6.3 \%$ fewer new entrepreneurs.

However, the marginal effect of corruption and its level of significance have to be interpreted conditional on the interaction with the costs of starting a new business (see Friedrich 1982). The marginal effects at the minimum and maximum values are also shown in the lower part of the table. At zero cost of starting a business, an increase in the corruption index by one point reduces entrepreneurship by $0.31 \% .{ }^{14}$ At its maximum of 131.3 , a corresponding increase in corruption increases entrepreneurship by $4.2 \%$. While the conditional effect is not significant at the minimum level of regulation, the effect is significant at the $1 \%$ level for maximum regulation, lending support to the strong form of the 'grease the wheels' hypothesis. Our findings are also relevant economically. The sample average for firm startups is $5.3 \%$ (see Appendix A). Thus, our results indicate that (in the presence of the most stringent regulation) entrepreneurship may almost be doubled by an increase in corruption (by one point on the ordinal scale).

Column 2 instead focuses on the minimum capital required to start a business. The regression reveals a similar picture. At the $1 \%$ level of significance, stricter capital requirements reduce entrepreneurial activity, while the effect of corruption becomes more positive. Again, the marginal effect is significant for the largest value of required capital $(946.7 \%$ of per capita GDP), but not when capital requirements are zero. An increase in the corruption index by one point does not affect entrepreneurship in the absence of regulations, but increases entrepreneurship by almost $10 \%$ at the maximum level of regulation.

Turning to the numbers of days and procedures required to start a business, the results are again similar. With a minimum of two days required, an increase in corruption by one point reduces entrepreneurship by $0.7 \%$ (at the 5\% level of significance). At the maximum of 152 days, the increase in entrepreneurship amounts to $3 \%$ (column 3 ). The corresponding increase in the maximum number of procedures (17) is $1.7 \%$.

Column 5 reports the results for the Economic Freedom sub-index on regulations. At the $10 \%$ level of significance, corruption reduces entrepreneurship at the index minimum (1.5).

\footnotetext{
${ }^{13}$ Note that the results do not depend on the functional form of per capita GDP and its square. As potential alternatives we have run regressions using log (GDP per capita) and its square, as well as GDP per capita without its squared term (with and without taking logs).

${ }^{14}$ Note that the corruption index is to some extent ordinal rather than cardinal. It is therefore not obvious that an increase from 1 to 2, for example, corresponds to an increase from 4 to 5 . However, the corruption index is usually treated as cardinal, assuming a linear scale of the ordinal index. See Mauro (1998), Treisman (2000), Méon and Sekkat (2005), Méon and Weill (2010), among many others.
} 
Table 3 Nascent entrepreneurship and corruption (World Bank), 2003-2005

\begin{tabular}{|c|c|c|c|c|c|}
\hline & (1) & (2) & (3) & (4) & (5) \\
\hline Lagged GDP per capita & $\begin{array}{l}-0.0006 \\
(2.65)^{* * *}\end{array}$ & $\begin{array}{l}-0.0007 \\
(2.71)^{* * *}\end{array}$ & $\begin{array}{l}-0.0006 \\
(3.35)^{* * *}\end{array}$ & $\begin{array}{l}-0.0006 \\
(2.92)^{* * *}\end{array}$ & $\begin{array}{l}-0.0007 \\
(4.18)^{* * *}\end{array}$ \\
\hline $\begin{array}{l}\text { Lagged GDP per capita } \\
\text { squared }\end{array}$ & $\begin{array}{l}1.08 \mathrm{E}-08 \\
(2.50)^{* *}\end{array}$ & $\begin{array}{l}1.42 \mathrm{E}-08 \\
(2.83)^{* * *}\end{array}$ & $\begin{array}{l}1.13 \mathrm{E}-08 \\
(3.04)^{* * *}\end{array}$ & $\begin{array}{l}1.16 \mathrm{E}-08 \\
(2.75)^{* * *}\end{array}$ & $\begin{array}{l}1.30 \mathrm{E}-08 \\
(3.72)^{* * *}\end{array}$ \\
\hline $\begin{array}{l}\text { Dummy for communist } \\
\text { history }\end{array}$ & $\begin{array}{l}-5.5527 \\
(3.55)^{* * *}\end{array}$ & $\begin{array}{l}-5.5479 \\
(4.06)^{* * *}\end{array}$ & $\begin{array}{l}-5.3752 \\
(4.30)^{* * *}\end{array}$ & $\begin{array}{l}-6.1670 \\
(3.59)^{* * *}\end{array}$ & $\begin{array}{l}-6.6376 \\
(4.19)^{* * *}\end{array}$ \\
\hline $\begin{array}{l}\text { World Bank Control of } \\
\text { Corruption }\end{array}$ & $\begin{array}{c}-0.1391 \\
(0.17)\end{array}$ & $\begin{array}{l}0.4267 \\
(0.46)\end{array}$ & $\begin{array}{l}-1.3242 \\
(1.60)\end{array}$ & $\begin{array}{l}-1.3416 \\
(1.05)\end{array}$ & $\begin{array}{c}-2.8858 \\
(1.69)^{*}\end{array}$ \\
\hline $\begin{array}{l}\text { Costs of starting a } \\
\text { business }\end{array}$ & $\begin{array}{l}0.0129 \\
(0.53)\end{array}$ & & & & \\
\hline Corruption $*$ costs & $\begin{array}{c}0.0753 \\
(2.69)^{* * *}\end{array}$ & & & & \\
\hline $\begin{array}{l}\text { Minimum capital required } \\
\text { to start a business }\end{array}$ & & $\begin{array}{l}-0.0176 \\
(4.70)^{* * *}\end{array}$ & & & \\
\hline $\begin{array}{l}\text { Corruption } * \text { capital } \\
\text { required }\end{array}$ & & $\begin{array}{c}0.0219 \\
(4.97)^{* * *}\end{array}$ & & & \\
\hline $\begin{array}{l}\text { Days required to start a } \\
\text { business }\end{array}$ & & & $\begin{array}{l}0.0286 \\
(1.22)\end{array}$ & & \\
\hline Corruption $*$ days & & & $\begin{array}{c}0.0504 \\
(4.13)^{* * *}\end{array}$ & & \\
\hline $\begin{array}{l}\text { Procedures required to } \\
\text { start a business }\end{array}$ & & & & $\begin{array}{c}-0.0527 \\
(0.24)\end{array}$ & \\
\hline Corruption $*$ procedures & & & & $\begin{array}{c}0.3323 \\
(3.22)^{* * *}\end{array}$ & \\
\hline $\begin{array}{l}\text { Economic Freedom } \\
\text { regulation sub-index }\end{array}$ & & & & & $\begin{array}{l}0.0687 \\
(0.09)\end{array}$ \\
\hline Corruption $*$ regulation & & & & & $\begin{array}{l}0.8120 \\
(1.88)^{*}\end{array}$ \\
\hline Constant & $\begin{array}{l}11.5167 \\
(4.87)^{* * *}\end{array}$ & $\begin{array}{l}13.6233 \\
(5.53)^{* * *}\end{array}$ & $\begin{array}{l}10.4437 \\
(6.67)^{* * *}\end{array}$ & $\begin{array}{l}12.7767 \\
(2.94)^{* * *}\end{array}$ & $\begin{array}{l}12.1049 \\
(2.63)^{* * *}\end{array}$ \\
\hline $\begin{array}{l}\text { M.E. of corruption cond. } \\
\text { on regulation }(\mathrm{min})\end{array}$ & -0.14 & 0.43 & -1.22 & -0.68 & -1.67 \\
\hline $\begin{array}{l}\text { M.E. of corruption cond. } \\
\text { on regulation }(\max )\end{array}$ & $9.75^{* * *}$ & $21.17^{* * *}$ & $6.33^{* * *}$ & $4.31^{* * *}$ & 1.66 \\
\hline Observations & 93 & 91 & 93 & 93 & 96 \\
\hline Countries & 43 & 42 & 43 & 43 & 42 \\
\hline $\begin{array}{l}\text { Joint significance } \\
\text { (p-value) }\end{array}$ & 0.038 & 0.000 & 0.000 & 0.000 & 0.001 \\
\hline R-squared & 0.55 & 0.54 & 0.58 & 0.56 & 0.50 \\
\hline
\end{tabular}

Notes: Corruption is measured on a scale between -2.51 and 1.71 , with larger values indicating more corruption. Higher values of all regulation variables indicate stricter regulation. Estimation is with heteroscedastic panel-corrected standard errors OLS and common AR(1) error term across panels. Joint significance refers to the p-value of a Wald test on corruption, the respective measure of regulation, and their interaction. Absolute z-statistics are given in parentheses. M.E. of corruption cond. on regulation represents the marginal effect of corruption conditional on the minimum ( $\min$ ) and maximum (max) of the regulation measure in the estimation sample

* Significant at $10 \% ;{ }^{* *}$ significant at $5 \% ;{ }^{* * *}$ significant at $1 \%$ 
Regulations significantly reduce entrepreneurship, while corruption seems to function as 'efficient grease', significantly alleviating this impact.

Table 3 replicates the analysis with Kaufmann et al.'s (2006) corruption index. As can be seen, the previous results are confirmed. In all regressions, the interaction term is significant at the $10 \%$ level at least, with the expected positive coefficient. The marginal effects at maximum regulation are significant at the $1 \%$ level in all but the final specification. The results show that an increase in the corruption index by one point increases entrepreneurship by $9.8 \%$ at the maximum costs level and by $21 \%$ for maximal capital requirements. The corresponding values for the other measures of regulation are $6.3 \%$ (days required to start a business) and $4.3 \%$ (procedures required to start a business). ${ }^{15}$

Figure 1 shows the results of the marginal effects of the two corruption measures, conditional on the number of days required to start a new business. ${ }^{16}$ The left panel depicts the results of the Transparency International measure, while the right panel shows the result of the World Bank variable. In the figures, each dot represents one observation. The upper and lower lines represent the 90 percent confidence interval. The results for both measures are very similar. The 'greasing' effect of corruption kicks in at around 50 days required to start a new business. In the absence of regulation, corruption is harmful for new firms. ${ }^{17}$ Our results thus provide support for the strong form of the 'grease the wheels' hypothesis according to the definition of Méon and Weill (2010).

To test for robustness, we replicate our analysis replacing the dependent variable. As an alternative, we use the total entrepreneurial activity index as our left-hand side variable. In addition to nascent entrepreneurs, this variable also includes newly founded enterprises, i.e., firms that have existed for longer than three months but less than 42 months. Again the percentage of entrepreneurs relative to the adult population is measured. Using this alternative dependent variable, we re-run the regressions presented in Tables 2 and 3. The results are extremely robust and yield almost identical implications. If anything, the relationship between entrepreneurship, corruption and regulation becomes stronger. Overall, our central findings prevail: The interaction between regulations and corruption remains significant even when looking at the unconditional effect. All our findings with respect to the conditional effects and their significance prevail without exception. ${ }^{18}$

We also test whether our results are driven by extreme values of either corruption or regulation. We do so by re-running our regressions excluding the top and bottom $5 \%$, both

\footnotetext{
${ }^{15}$ Potentially, strict regulations might drive entrepreneurs away from the official sector to the shadow economy (e.g., Antunes and de V. Cavalcanti 2007; Dreher et al. 2009). When corruption is a substitute for the shadow economy, our results might be driven by the underground economy rather than reflecting the impact of corruption per se. However, activities in the shadow economy might also be "taxed" by officials seeking bribes. When we include a variable measuring the size of a country's shadow economy (Schneider and Enste 2000; Schneider 2005a, 2005b) to our regressions, the results are not affected. The coefficient of the shadow economy itself is insignificant in all specifications. This is in line with Méon et al. (2011), reporting a very small effect of the shadow economy on aggregate efficiency.

${ }^{16} \mathrm{We}$ also calculated the marginal effect of regulation conditional on corruption. We find that the marginal effect of regulation increases with corruption. Specifically, regulatory barriers do not adversely affect entry in corrupt countries, while they do in less corrupt ones. This is in line with Klapper et al. (2006). The figures are available on request.

${ }^{17}$ For the sake of brevity, we suppress the graphs for the other regulation measures. They all exhibit the same pattern and are available on request.

${ }^{18}$ As further test for robustness, we also replicated our results using the ICRG index of corruption. We do not report the results, as this index captures the political risk involved in corruption rather than corruption per se. The general results are very similar to those reported here.
} 

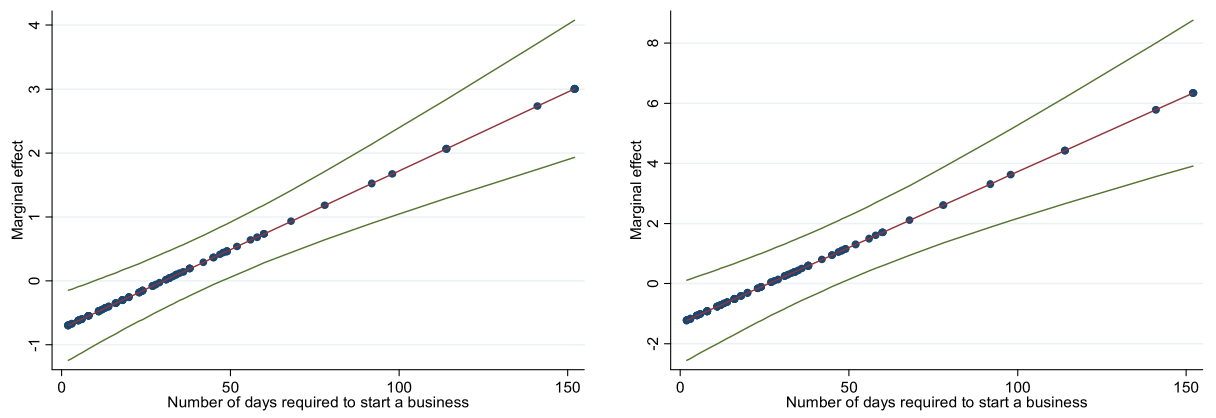

Fig. 1 Marginal effect of corruption on nascent entrepreneurship. Notes: The figure visualizes the marginal effects of corruption conditional on the number of days required to start a business. The results are based on column (3) of Tables 2 and 3, respectively. The left panel displays the results for the Transparency International index while the right panel utilizes the World Bank corruption index. Each dot represents one observation. Furthermore, the $90 \%$ confidence interval is displayed

Table 4 Robustness test of the 'grease the wheels' - effect

\begin{tabular}{lll}
\hline & Transparency International & World Bank \\
\hline Costs of starting a business & 0.100 & 0.093 \\
Minimum capital required to start a business & 0.004 & 0.003 \\
Days required to start a business & 0.101 & 0.045 \\
Procedures required to start a business & 0.083 & 0.073 \\
Economic Freedom regulation sub-index & 0.082 & 0.039 \\
\hline
\end{tabular}

Notes: The table gives the results of the EBAs as discussed in Table 1. We report only the average p-values of Wald tests that the three coefficients on our regulation measure, our corruption measure and the interaction term between them are jointly equal to zero. Each entry in the table represents results from a separate EBA based on 4,691 regressions. The control variables included are listed in Appendix B

jointly and separately, for the two measures. Doing so leaves our findings qualitatively unchanged, with the exception of minimum capital requirements. We therefore conclude that extreme observations are not the drivers of our results. In a similar vein, we re-run our analysis excluding former communist countries. This leaves our findings unaffected.

As our final test for robustness, we check whether our results depend on the choice of control variables. We therefore replicate the EBA introduced above by including our measures of corruption and regulations, as well as the interaction term between the two. The results of this analysis are summarized in Table 4. The table shows the average p-value of the Wald test for joint significance for the three 'greasing the wheels' variables. Again, we calculate separate EBAs for each measure of regulation and each measure of corruption. The top left entry (costs of starting a business/Transparency International) gives the average pvalue for the joint significance test on costs, corruption, and their interaction based on 4,691 regressions. As can be seen, these three coefficients are significantly different from zero at the $10 \%$ level, on average. The table shows that this is true for all our combinations, except for the effect of days required to start a business on the Transparency International index, which is marginally insignificant.

To summarize, we find strong evidence in favor of the 'grease the wheels' hypothesis. While corruption hardly affects entrepreneurship when the economy is not heavily regu- 
lated, corruption increases entrepreneurial activity when regulations abound. We also find some evidence that-while strict regulations reduce entrepreneurial activity in the absence of corruption - this negative impact becomes less pronounced with more corruption.

\section{Conclusion}

The paper provides two contributions to the literature. First, and instrumental to our main question of interest, we test whether regulations robustly deter firm entry into markets. Our results show that some regulations indeed matter for entrepreneurial activity. Specifically, we find that if more procedures are required to start a business and minimal capital requirements are higher, they will be detrimental to entrepreneurship on average. Regarding control variables typically included in similar studies, we find the expected u-shaped relationship between GDP per capita and entrepreneurship. Moreover, countries with communist backgrounds have significantly fewer entrepreneurs. Testing for the robustness of the numerous additional determinants of entrepreneurship proposed in the previous literature, we find the average income tax rate, secondary school enrolment and the share of tax revenue in GDP to be robustly related to entrepreneurial activity.

As our main contribution, we tested whether corruption can be an efficient 'grease', reducing the negative impact of regulations on entrepreneurship in highly regulated economies. Arguably, this is a more effective way of testing the 'grease the wheels' hypothesis than using economic growth rates, as has been done elsewhere. Clearly the impact of circumventing regulations on economic growth can only be an indirect one, thus it is not surprising that most studies focusing on growth did not find much evidence in favor of a beneficial impact of corruption. We employ a more direct test, focusing on the variable that regulations to market entry are most likely to affect: The number of new entrepreneurs (in percent of the total adult population). Our empirical analysis for a maximum of 43 countries over the 2003-2005 period shows that corruption can indeed be beneficial. At the maximum level of regulation in our sample of countries, public corruption increases private entrepreneurial activity significantly. As such, corruption might be viewed as being beneficial rather than harmful. This conclusion, however, warrants some caution. First, larger numbers of entrepreneurs entering the market are not necessarily beneficial to society. If regulations effectively block the entry of firms that are likely to fail, or those that supply goods and services that the government wants to prevent from being offered to the market, then more entrepreneurial activity might be socially wasteful. We cannot test those alternatives with our data.

Second, our analysis neglects potential long-term feedbacks from corruption to regulations. While it seems reasonable to assume that corruption and regulations are both exogenous to the entrepreneur's decision to enter the market in the short run, this might not be true in the longer term. There is some evidence that frictions are introduced to allow corrupt officials to extract rents. According to Myrdal (1986), corrupt officials cause delays so that they gain the opportunity to ask for bribes. Edwards (1999) and DeLong and Eichengreen (2002) argue that controls might breed corruption. Shleifer and Vishny (1993) emphasize that the imposition of capital controls for example makes it easier to collect bribes. Dreher and Siemers (2009) show that more corruption is associated with more restrictions on the capital account, while Djankov et al. (2002) find that entry regulations are more stringent as corruption among public officials becomes wider and deeper.

When regulations are introduced by corrupt officials to allow for the extraction of bribes, the level of regulation in a country will rise in the long-run as a consequence of corruption. 
As regulations prevent firms from entering the market and corruption can be used to alleviate this impact, we cannot know which effect on the allocation of resources dominates. While the potential endogeneity of regulation and governmental corruption does not pose a problem for identifying the mechanism of interest in this paper, studying the longer-term consequences of regulation and corruption would require endogenizing a country's level of corruption. We leave this for future research.

Open Access This article is distributed under the terms of the Creative Commons Attribution Noncommercial License which permits any noncommercial use, distribution, and reproduction in any medium, provided the original author(s) and source are credited.

Appendix A: Sources and descriptive statistics for the key variables

\begin{tabular}{|c|c|c|c|c|c|}
\hline Variable & Source & Mean & Std. Dev. & Min & $\operatorname{Max}$ \\
\hline Nascent entrepreneurship & $\begin{array}{l}\text { Global Entrepreneurship } \\
\text { Monitor }\end{array}$ & 5.285 & 3.967 & 0.5 & 31.4 \\
\hline $\begin{array}{l}\text { GDP per capita (constant } \\
2000 \$ \text { ) }\end{array}$ & World Bank (2006) & 13091.7 & 11136.1 & 219.6 & 39004.9 \\
\hline $\begin{array}{l}\text { Dummy for communist } \\
\text { history }\end{array}$ & & 0.131 & 0.337 & 0 & 1 \\
\hline $\begin{array}{l}\text { Procedures required to } \\
\text { start a business }\end{array}$ & Doing Business & 8.647 & 3.905 & 2 & 19 \\
\hline $\begin{array}{l}\text { Days required to start a } \\
\text { business }\end{array}$ & Doing Business & 38.649 & 34.040 & 2 & 168 \\
\hline $\begin{array}{l}\text { Costs of starting a } \\
\text { business }\end{array}$ & Doing Business & 18.982 & 25.843 & 0 & 146.5 \\
\hline $\begin{array}{l}\text { Minimum capital required } \\
\text { to start a business }\end{array}$ & Doing Business & 47.632 & 103.105 & 0 & 946.7 \\
\hline $\begin{array}{l}\text { Economic Freedom } \\
\text { regulation sub-index }\end{array}$ & $\begin{array}{l}\text { Gwartney and Lawson } \\
\text { (2006) }\end{array}$ & 4.089 & 0.934 & 1.4 & 7.3 \\
\hline $\begin{array}{l}\text { Transparency } \\
\text { International corruption }\end{array}$ & $\begin{array}{l}\text { Transparency } \\
\text { International }\end{array}$ & 5.100 & 2.431 & 0 & 9.6 \\
\hline World Bank corruption & Kaufmann et al. (2006) & -0.205 & 1.094 & -2.51 & 1.71 \\
\hline
\end{tabular}

\section{Appendix B: Control variables included in the extreme bounds analysis}

\begin{tabular}{llll}
\hline Variable & Proposed by & Source & CDF \\
\hline $\begin{array}{l}\text { Average income tax (combined } \\
\text { central and sub-central government } \\
\text { taxes) }\end{array}$ & Parker and Robson (2004) & OECD (2007) & 0.94 \\
$\begin{array}{l}\text { Average of Net Replacement Rates } \\
\text { over 60 months of unemployment, } \\
\text { with social assistance }\end{array}$ & Parker and Robson (2004), & OECD (2007) & 0.85 \\
\hline
\end{tabular}


(Continued)

\begin{tabular}{|c|c|c|c|}
\hline Variable & Proposed by & Source & $\mathrm{CDF}$ \\
\hline $\begin{array}{l}\text { Average of Net Replacement Rates } \\
\text { over } 60 \text { months of unemployment, } \\
\text { without social assistance }\end{array}$ & $\begin{array}{l}\text { Parker and Robson (2004), } \\
\text { Wennekers et al. (2007) }\end{array}$ & OECD (2007) & 0.63 \\
\hline $\begin{array}{l}\text { Bank nonperforming loans to total } \\
(\%)\end{array}$ & Ovaska and Sobel (2005) & World Bank (2006) & 0.54 \\
\hline $\begin{array}{l}\text { Domestic credit to private sector } \\
(\% \text { of GDP) }\end{array}$ & Ovaska and Sobel (2005) & World Bank (2006) & 0.73 \\
\hline $\begin{array}{l}\text { Employer social security } \\
\text { contributions }\end{array}$ & Parker and Robson (2004) & OECD (2007) & 0.53 \\
\hline $\begin{array}{l}\text { Employment in services (\% of total } \\
\text { employment) }\end{array}$ & $\begin{array}{l}\text { Verheul et al. (2006), } \\
\text { Wennekers et al. (2007) }\end{array}$ & World Bank (2006) & 0.66 \\
\hline $\begin{array}{l}\text { Female employment share (females } \\
\text { employed/total females, both } \\
\text { 15-64) }\end{array}$ & $\begin{array}{l}\text { Noorderhaven et al. (2004), } \\
\text { Verheul et al. (2006), } \\
\text { Wennekers et al. (2007) }\end{array}$ & OECD (2007) & 0.59 \\
\hline $\begin{array}{l}\text { Female participation rate (female } \\
\text { labor force/female population, both } \\
\text { 15-64) }\end{array}$ & Parker and Robson (2004) & OECD (2007) & 0.65 \\
\hline $\begin{array}{l}\text { Foreign direct investment, inflows } \\
(\% \text { of GDP) }\end{array}$ & Ovaska and Sobel (2005) & World Bank (2006) & 0.53 \\
\hline GDP per capita growth (annual \%) & van Stel et al. (2003) & World Bank (2006) & 0.59 \\
\hline $\begin{array}{l}\text { Health expenditure, total ( } \% \text { of } \\
\text { GDP) }\end{array}$ & Freytag and Thurik (2007) & World Bank (2006) & 0.82 \\
\hline $\begin{array}{l}\text { Industry, value added (annual } \\
\% \text { growth) }\end{array}$ & Scarpetta et al. (2002) & World Bank (2006) & 0.64 \\
\hline $\begin{array}{l}\text { Inflation, consumer prices } \\
(\text { annual \%) }\end{array}$ & Ovaska and Sobel (2005) & World Bank (2006) & 0.75 \\
\hline Internet users (per 1,000 people) & van Stel et al. (2003) & World Bank (2006) & 0.52 \\
\hline Labor force, female (\% of total) & $\begin{array}{l}\text { Noorderhaven et al. (2004), } \\
\text { Verheul et al. (2006), } \\
\text { Wennekers et al. (2007) }\end{array}$ & World Bank (2006) & 0.53 \\
\hline $\begin{array}{l}\text { Life expectancy at birth, total } \\
\text { (years) }\end{array}$ & Freytag and Thurik (2007) & World Bank (2006) & 0.53 \\
\hline Long term interest rate & Wennekers et al. (2007) & OECD (2007) & 0.64 \\
\hline $\begin{array}{l}\text { Population density (people per sq. } \\
\text { km) }\end{array}$ & $\begin{array}{l}\text { Noorderhaven et al. (2004), } \\
\text { Wennekers et al. (2007) }\end{array}$ & World Bank (2006) & 0.84 \\
\hline $\begin{array}{l}\text { Research and development } \\
\text { expenditure (\% of GDP) }\end{array}$ & Verheul et al. (2006) & World Bank (2006) & 0.77 \\
\hline $\begin{array}{l}\text { School enrollment, secondary } \\
\text { (\% gross) }\end{array}$ & $\begin{array}{l}\text { Uhlaner and Thurik (2007), } \\
\text { Wennekers et al. (2007) }\end{array}$ & World Bank (2006) & 0.90 \\
\hline $\begin{array}{l}\text { School enrollment, tertiary } \\
\text { (\% gross) }\end{array}$ & $\begin{array}{l}\text { Uhlaner and Thurik (2007), } \\
\text { Wennekers et al. (2007) }\end{array}$ & World Bank (2006) & 0.64 \\
\hline $\begin{array}{l}\text { Services, etc., value added ( } \% \text { of } \\
\text { GDP) }\end{array}$ & Parker and Robson (2004) & World Bank (2006) & 0.69 \\
\hline $\begin{array}{l}\text { Share of } 25-39 \text { year olds in group } \\
\text { of } 25-64\end{array}$ & Wennekers et al. (2007) & OECD (2007) & 0.67 \\
\hline Social contributions ( $\%$ of revenue) & van Stel et al. (2003) & World Bank (2006) & 0.87 \\
\hline $\begin{array}{l}\text { Statutory corporate income tax } \\
\text { rates (top marginal rate if } \\
\text { applicable) }\end{array}$ & van Stel et al. (2003) & OECD (2007) & 0.88 \\
\hline
\end{tabular}


(Continued)

\begin{tabular}{llll}
\hline Variable & Proposed by & Source & CDF \\
\hline Tax revenue (\% of GDP) & van Stel et al. (2003) & World Bank (2006) & 0.91 \\
$\begin{array}{l}\text { Taxes on income, profits and } \\
\text { capital gains (\% of revenue) }\end{array}$ & van Stel et al. (2003), & World Bank (2006) & 0.89 \\
$\begin{array}{l}\text { Taxes on international trade (\% of } \\
\text { revenue) }\end{array}$ & Ovaska and Sobel (2005) & World Bank (2006) & 0.82 \\
$\begin{array}{l}\text { Unemployment, total (\% of total } \\
\text { labor force) }\end{array}$ & van Stel et al. (2003), & World Bank (2006) & 0.74 \\
& Noorderhaven et al. (2004), & & \\
& Parker and Robson (2004), & & \\
& Verheul et al. (2006), & & \\
& Wennekers et al. (2007) & & \\
\hline
\end{tabular}

\section{Appendix C: List of countries included}

Argentina, Australia, Austria, Belgium, Brazil, Canada, Chile, China, Croatia, Denmark, Ecuador, Finland, France, Germany, Greece, Hong Kong, Hungary, Iceland, Ireland, Israel, Italy, Jamaica, Japan, Jordan, Latvia, Mexico, New Zealand, Norway, Peru, Poland, Portugal, Singapore, Slovenia, South Africa, Spain, Sweden, Switzerland, Thailand, The Netherlands, Uganda, United Kingdom, USA, Venezuela.

\section{References}

Anderson, C., \& Tverdova, Y. (2003). Corruption, political allegiances, and attitudes toward government in contemporary democracies. American Political Science Review, 47(1), 91-109.

Antunes, A. R., \& de V. Cavalcanti, T. V. (2007). Start up costs, limited enforcement, and the hidden economy. European Economic Review, 51(1), 203-224.

Bailey, D. H. (1966). The effects of corruption in a developing nation. Western Political Quarterly, 19(4), 719-732.

Beck, N., \& Katz, J. N. (1995). What to do (and not to do) with time-series cross-section data. American Political Science Review, 89(3), 634-647.

Beck, N., \& Katz, J. N. (1996). Nuisance vs. substance: specifying and estimating time-series cross-section models. Political Analysis, 6(1), 1-36.

Beck, P. J., \& Mahler, M. W. (1986). A comparison of bribery and bidding in thin markets. Economics Letters, 20(1), 1-5.

Bjørnskov, C., \& Foss, N. J. (2008). Economic freedom and entrepreneurial activity: some cross-country evidence. Public Choice, 134(3), 307-328.

Blankart, C. B. (2003). Öffentliche Finanzen in der Demokratie (5th ed.). Munich: Vahlen.

Campos, J. E., Lien, D., \& Pradhan, S. (1999). The impact of corruption on investment: predictability matters. World Development, 27(6), 1059-1067.

Campos, N., Dimova, R., \& Saleh, A. (2010). Whither corruption? A quantitative survey of the literature on corruption and growth (CEPR Discussion Paper No. 8140).

Ciccone, A., \& Papaioannou, E. (2007). Red tape and delayed entry. Journal of the European Economic Association, 5(2-3), 444-458.

DeLong, B., \& Eichengreen, B. (2002). Between meltdown and moral hazard: the international monetary and financial policies of the Clinton administration. In J. Frankel \& P. Orszag (Eds.), American economic policy in the 1990s (pp. 191-254). Cambridge: MIT Press.

Desai, M., Gompers, P., \& Lerner, J. (2003). Institutions, capital constraints and entrepreneurial firm dynamics: evidence from Europe (NBER Working Paper 10165).

Djankov, S., La Porta, R., Lopes-de-Silanes, F., \& Shleifer, A. (2002). The regulation of entry. Quarterly Journal of Economics, 117(1), 1-37.

Dreher, A., \& Siemers, L.-H. R. (2009). The intriguing nexus between corruption and capital account restrictions. Public Choice, 140(1-2), 245-265. 
Dreher, A., Kotsogiannis, C., \& McCorriston, S. (2009). How do institutions affect corruption and the shadow economy? International Tax and Public Finance, 16(6), 773-796.

Edwards, S. (1999). How effective are capital controls? Journal of Economic Perspectives, 13(4), 65-84.

Freytag, A., \& Thurik, R. (2007). Entrepreneurship and its determinants in a cross-country setting. Journal of Evolutionary Economics, 17(2), 117-131.

Friedrich, R. J. (1982). In defense of multiplicative terms in multiple regression equations. American Journal of Political Science, 26(4), 797-833.

Gwartney, J., \& Lawson, R. (2006). Economic freedom of the world: 2006 annual report. Vancouver: Fraser Institute.

Huntington, S. P. (1968). Political order in changing societies. New Haven: Yale University Press.

Kaufman, D., \& Wei, S.-J. (2000). Does 'grease money' speed up the wheels of commerce? (IMF Working Paper 00/64).

Kaufmann, D., Kraay, A., \& Mastruzzi, M. (2006). Governance matters V: governance indicators for 19962005. World Bank Institute.

Klapper, L., Laeven, L., \& Rajan, R. (2006). Entry regulation as a barrier to entrepreneurship. Journal of Financial Economics, 82(3), 591-629.

Kurer, O. (1993). Clientelism, corruption and the allocation of resources. Public Choice, 77(2), 259-273.

Leff, N. H. (1964). Economic development through bureaucratic corruption. American Behavioral Scientist, 8(3), 8-14.

Leamer, E. E. (1983). Let's take the con out of econometrics. American Economic Review, 73(1), 31-43.

Levine, R., \& Renelt, D. (1992). A sensitivity analysis of cross-county growth regressions. American Economic Review, 82(4), 942-963.

Leys, C. (1965). What is the problem about corruption? Journal of Modern African Studies, 3(2), 215-230.

Lien, D. H. D. (1986). A note on competitive bribery games. Economics Letters, 22(4), 337-341.

Lui, F. T. (1985). An equilibrium queuing model of bribery. Journal of Political Economy, 93(4), 760-781.

Mauro, P. (1998). Corruption and the composition of government expenditures. Journal of Public Economics, 69(2), 263-279.

Méon, P.-G., \& Sekkat, K. (2005). Does corruption grease or sand the wheels of growth? Public Choice, 122(1), 69-97.

Méon, P.-G., \& Weill, L. (2010). Is corruption an efficient grease? World Development, 38(3), 244-259.

Méon, P.-G., Schneider, F., \& Weill, L. (2011). Does taking the shadow economy into account matter to measure aggregate efficiency? Applied Economics, 43(18), 2303-2311.

Minniti, M., Bygrave, W. D., \& Autio, E. (2005). Global entrepreneurship monitor 2005 executive report. Wellesley: Babson College.

Musgrave, R. A. (1959). The theory of public finance. New York: McGraw Hill.

Myrdal, G. (1986). Asian drama: an enquiry into the poverty of nations (Vol. 2). New York: Twentieth Century Fund.

Noorderhaven, N., Thurik, R., Wennekers, S., \& van Stel, A. (2004). The role of dissatisfaction and per capita income in explaining self-employment across 15 European countries. Entrepreneurship Theory and Practice, 28(5), 447-466.

Nye, J. (1967). Corruption and political development: a cost-benefit analysis. American Political Science Review, 61(2), 417-427.

OECD (2007). Statistical compendium. CD-Rom. Paris: OECD.

Ovaska, T., \& Sobel, R. S. (2005). Entrepreneurship in post-Socialist economies. Journal of Private Enterprise, 21(1), 8-28.

Parker, S. C., \& Robson, M. T. (2004). Explaining international variations in self-employment: evidence from a panel of OECD countries. Southern Economic Journal, 71(2), 287-301.

Pigou, A. C. (1928). A study in public finance (3rd ed., 1947). London: Macmillian.

Rose-Ackerman, S. (1997). The political economy of corruption. In K. A. Elliott (Ed.), Corruption and the global economy (pp. 31-60). Washington: Institute for International Economics.

Rose-Ackerman, S. (1999). Corruption and government: causes, consequences, and reform. Cambridge: Cambridge University Press.

Sala-i-Martin, X. (1997). I just ran two million regressions. American Economic Review, 87(2), 178-183.

Sala-i-Martin, X., Doppelhofer, G., \& Miller, R. I. (2004). Determinants of long-term growth: a Bayesian averaging of classical estimates (BACE) approach. American Economic Review, 94(4), 813-835.

Scarpetta, S., Hemmings, P., Tressel, T., \& Woo, J. (2002). The role of policy and institutions for productivity and firm dynamics: evidence from micro and industry data (Working Paper No. 329). OECD Economics Department.

Schneider, F. (2005a). Shadow economies around the world: what do we really know? European Journal of Political Economy, 21(3), 598-642. 
Schneider, F. (2005b). Shadow economies of 145 countries all over the world: estimation results of the period 1999-2003 (Discussion Paper). Department of Economics, University of Linz.

Schneider, F., \& Enste, D. H. (2000). Shadow economies: size, causes, and consequences. Journal of Economic Literature, 38(1), 77-114.

Shleifer, A., \& Vishny, W. (1993). Corruption. Quarterly Journal of Economics, 108(3), 599-617.

Stigler, G. J. (1971). The theory of economic regulation. Bell Journal of Economics, 2(1), 3-21.

Sturm, J.-E., \& de Haan, J. (2002). How robust is Sala-i-Martin's robustness analysis? (Mimeo). University of Konstanz.

Tanzi, V. (1998). Corruption around the world: causes, consequences, scope, and cures. IMF Staff Papers, 45(4), 559-594.

Temple, J. (2000). Growth regressions and what the textbooks don't tell you. Bulletin of Economic Research, 52(3), 181-205.

Treisman, D. (2000). The causes of corruption: a cross-national study. Journal of Public Economics, 76(3), 399-457.

Uhlaner, L., \& Thurik, R. (2007). Postmaterialism influencing total entrepreneurial activity across nations. Journal of Evolutionary Economics, 17(2), 161-185.

van Stel, A., Wennekers, S., Thurik, R., \& de Wit, G. (2003). Explaining nascent entrepreneurship across countries (SCALES Working Paper No 200301).

Verheul, I., van Stel, A., \& Thurik, R. (2006). Explaining female and male entrepreneurship at the country level. Entrepreneurship and Regional Development, 18(2), 151-183.

Vial, V., \& Hanoteau, J. (2010). Corruption, manufacturing plant growth, and the Asian paradox: Indonesian evidence. World Development, 38(5), 693-705.

Wennekers, S., \& Thurik, R. (1999). Linking entrepreneurship and economic growth. Small Business Economics, 13(1), 27-55.

Wennekers, S., Thurik, R., van Stel, A., \& Noorderhaven, N. (2007). Uncertainty avoidance and the rate of business ownership across 21 OECD countries, 1976-2004. Journal of Evolutionary Economics, 17(2), $133-160$

World Bank (2006). World development indicators. CD-Rom. Washington: World Bank. 